\title{
A infância e o futuro da nação: \\ a criança e a (bio) política da esperança na Paraíba (1940-1950)
}

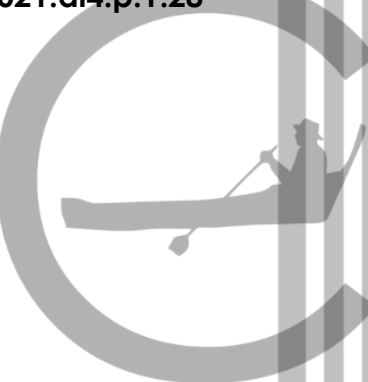

José dos Santos Costa Júnior ${ }^{1}$

\begin{abstract}
Resumo
O texto analisa as condições de emergência de narrativas que articularam a infância e o futuro da nação brasileira nas décadas de 1940 e 1950. Constam do corpus documental o Boletim da comissão estadual da Legião Brasileira de Assistência na Paraíba (LBA), assim como os periódicos A União (jornal oficial do governo do estado) e o jornal católico A Imprensa. Assim, problematiza-se: como e em que condições de possibilidade as políticas para a infância foram articuladas por uma concepção do tempo histórico que agenciou o sentimento de esperança no progresso da nação? O referencial teóricometodológico parte da genealogia de Michel Foucault para analisar o discurso como uma prática que institui os objetos de que fala. Por meio da crítica da linguagem e do processo de constituição de sujeitos em relações de poder, frisa-se as tecnologias biopolíticas de governo da infância, assim como os efeitos gerados sobre os corpos infantis. Destaca o papel da LBA como política social e educativa que esteve articulada a propostas do Departamento Nacional da Criança $(\mathrm{DNCr})$ e do Fundo Internacional de Socorro à Infância (FISI), agência da Organização das Nações Unidas (ONU) que atuou na Paraíba com enfoque na questão do direito à alimentação e saúde infantil.
\end{abstract}

Palavras chaves: História da Infância e da Juventude; História da Paraíba; Estudos foucaultianos.

\begin{abstract}
The text analyzes the conditions of emergence of narratives that articulated childhood and the future of the Brazilian nation in the 1940s and 1950s. The documental corpus includes the Bulletin of the State Committee of the Brazilian Assistance Legion in Paraíba (LBA), as well as periodicals A União (official newspaper of the state government) and the Catholic newspaper A Imprensa. Thus, the question is: how and under what conditions of possibility were policies for childhood articulated by a conception of historical time that brought about the feeling of hope in the nation's progress? The theoretical-methodological framework starts from Michel Foucault's genealogy to analyze discourse as a practice that institutes the objects it speaks about. Through the critique of language and the process of constitution of subjects in power relations, it emphasizes the biopolitical technologies of childhood governance, as well as the effects generated on children's bodies. It highlights the role of LBA as a social and educational policy that was articulated with proposals from the National Department of Children (DNCr) and the International Child Relief
\end{abstract}

\footnotetext{
${ }^{1}$ Doutor em História pela Universidade Federal do Rio Grande, do Sul (UFRGS). Pesquisador do Núcleo de História e Linguagens Contemporâneas da Universidal stadual da Paraíba (NUHLC/UEPB). E-mail: jose.junior010@gmail.com

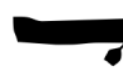


Fund (FISI), an agency of the United Nations (UN) that worked in Paraíba with a focus on the issue of the right to food and child health.

Keywords: Childhood and Youth History; History of Paraiba; Foucaultian studies.

\section{Introdução}

Narrando a história de um homem que, após perder o emprego, abandonou a sua família e passou a morar na rua, chegando ao ponto de esquecer o próprio nome, o escritor Moacyr Scliar toca em uma chaga aberta na história do Brasil. O contista sequer situa a história no terreno brasileiro, mas este artigo mobiliza o conto para pensar a história do Brasil, especificamente no século XX. Ao esquecer dos rostos de seus filhos e sua esposa, o homem também esqueceu de si próprio, nomeando-se como José da Silva (um nome trivial) diante do padre que lhe ofereceu um banho, roupas limpas e comida. Ao ouvir "José da Silva" como resposta, o padre olhou com consternação, pois certamente aquele era o nome mais adotado pelos que ali passavam. Depois do banho e com a sensação de limpeza, o homem caminhou mais tranquilo pela cidade. Estava tão embriagado pelo sol, pelas luzes do dia e pela movimentação nas ruas que, ao passar pela avenida, não viu o ônibus que o atingiu fortemente. Porém, a sensação de leveza permanecia em seu corpo imóvel, e já agonizante sob o asfalto quente. As pessoas o olhavam curiosas e foi aí que um policial se aproximou, dizendo:

- "Como é que está, cidadão? Dá para aguentar cidadão?"2

Naquele momento ele se deu conta, à beira da morte, que não tinha um nome, mas tinha um título: cidadão. Essa tragédia nos ajuda a pensar sobre a formação histórica da cidadania. O conto demonstra como o fato de não ter mais um emprego, uma carteira de identidade e uma carteira de trabalho relegou aquele indivíduo ao esquecimento. Como poderia um homem, na sociedade urbana e industrial moderna, não ocupar um lugar na cadeia produtiva? Esse pretenso "sujeito universal" que a modernidade criou a partir dos séculos XVII e XVIII continua sendo uma abstração frente às singularidades e formas diversas de inserção social. ${ }^{3}$

\footnotetext{
${ }^{2}$ SCLIAR, Moacyr. O nascimento de um cidadão. In. PINSKY, Jaime \& PINSKY, Carla Bassanezi (org). História da cidadania. $6^{a}$ ed. São Paulo: Contexto, 2018, pp. 567-570.

${ }^{3}$ Para uma discussão sobre a construção social dos conceitos de igualdade e diferença, assim como a problemática do "sujeito universal" cf. SCOTT, Joan. O enigma da igualdade. Estudos Feministas, Florianópolis, v. 13, n. 1, janeiro-abril, 2015.
} 
Se a conquista de um conjunto de direitos civis e políticos a partir do século XVIII nos permite entender a história da cidadania, por outro lado também nos convida a situar o lugar dessa conquista, os sujeitos singulares que a produziram e aqueles que foram "objeto" e horizonte dessa definição, como analisa a historiadora Lynn $\mathrm{Hunt}^{4}$ ao problematizar a invenção dos direitos humanos a partir da experiência da Revolução de Independência das treze colônias que originaram os Estados Unidos da América (EUA) em 1776, a Revolução Francesa de 1789 e o contexto pós Segunda Guerra Mundial que deu origem à Organização das Nações Unidas (ONU) e a célebre Declaração Universal dos Direitos Humanos (DUDH) em 1948.

Embora o conto de Scliar se intitule $O$ nascimento de um cidadão, a provocação situa-se no fato de que isto se deu no momento da morte. Tal aspecto nos faz pensar sobre o lugar do cidadão na sociedade, as condições que o definem dessa forma e as possibilidades abertas ou interditadas a depender das situações vivenciadas pelo indivíduo. Portanto, este texto, diferentemente do conto de Moacyr Scliar, debruça-se sobre uma experiência histórica específica que também fabricou uma concepção de cidadania e de sujeito categorizado como "cidadão". O artigo analisa as condições de emergência histórica de narrativas sobre a infância e sua articulação com o futuro da nação brasileira nos anos 1940 e 1950, quando o ideário da "cidadania" instituiu políticas sociais e educativas que definiram o que a criança deveria ser, como deveria ser educada e formada para vir a se tornar um cidadão ou uma cidadã no futuro. Para isso, mobilizase um corpus documental composto pelo boletim da comissão estadual da Legião Brasileira de Assistência (LBA) na Paraíba, e periódicos como A União (jornal oficial do governo do Estado) e o jornal católico A Imprensa. O texto demonstra como essas políticas públicas construídas com enfoque na infância e maternidade estiveram articuladas a uma certa concepção do que era o tempo histórico. Urdiu-se uma ideia positivada do futuro como o tempo de realização das promessas para a infância e para a nação que almejava tornar-se grande, rica e próspera. Assim, a noção de tempo histórico marcada pelo termo "esperança", reiteradamente dito nas fontes da época, remetia a um sentimento salvacionista em relação à "criança brasileira", assim como à clivagem entre presente/futuro marcado por promessas e projeções.

Um dos aspectos que marcou a construção desse sentimento de esperança foi a definição dos "Direitos da Criança Brasileira", como estava intitulado em uma das seções

\footnotetext{
${ }^{4}$ HUNT, Lynn. A invenção dos direitos humanos: uma história. Tradução de Rosaura Eichenberg. São Paulo: Companhia das Letras, 2009.
} 
do Boletim da LBA. Aquele era um cenário marcado pela ocorrência da Segunda Guerra Mundial (1939-1945), o acometimento da população por diversas doenças, o que gerou um sentimento de desamparo social em relação às famílias pobres. A própria criação da LBA em 1942 por Getúlio Vargas (1882-1954) e Darcy Vargas (1895-1968) foi uma resposta ao contexto de entrada do país na Segunda Guerra Mundial com os Aliados, grupo de países formado por Reino Unido, Estados Unidos, França e União Soviética.

\section{Do governo da infância}

A LBA foi criada inicialmente para assistir as famílias dos pracinhas, soldados enviados pela Força Expedicionária Brasileira (FEB), à guerra. Na prática uma série de problemas e carências sociais fez com que a instituição se voltasse para a maternidade e a infância. Com a formação da LBA e sua comissão central no Rio de Janeiro, então capital da república, outras comissões estaduais e municipais foram formadas, sendo presididas na maioria dos casos pelas esposas dos prefeitos e interventores federais. $\mathrm{Na}$ Paraíba a comissão estadual foi criada em outubro de 1942 por Alice Carneiro, primeiradama, durante a interventoria de Ruy Carneiro. A revista da LBA, intitulada Boletim da LBA, passou a ser publicada em junho de 1947.

Uma vez que partimos da análise de periódicos, como a revista da LBA, cabe lembrar que se uma revista, como o nome sugere, "passa em revista" uma série de assuntos, permitindo com isso uma leitura "fragmentada, não contínua, e por vezes seletiva", a leitura dessa fonte deve considerar que a sua periodicidade, os recortes temáticos contínuos ou descontínuos, assim como a materialidade que organiza as seções, fotografias e demais elementos da publicação, são fundamentais para compreender suas enunciações. ${ }^{5}$ Tânia Regina de Luca diz que "é importante estar alerta para os aspectos que envolvem a materialidade dos impressos e seus suportes, que nada têm de natural" ${ }^{\text {. }}$ A arquitetura discursiva de uma revista como a da LBA instituiu percepções e concepções sobre a infância, a maternidade, as ações do Estado e a própria concepção de temporalidade.

\footnotetext{
${ }^{5}$ MARTINS, Ana Luiza. Revistas em Revista: Imprensa e Práticas Culturais em Tempos de República, São Paulo (1890-1922). São Paulo: Editora da Universidade de São Paulo: FAPESP: Imprensa Oficial do Estado, 2001, p. 45.

${ }^{6}$ LUCA, Tania Regina de. História dos, nos e por meio dos periódicos. In. PINSKY, Carla Bassanezi. Fontes históricas. $2^{a}$ ed. São Paulo: Contexto, 2010, p. 132.
} 
Neste sentido, analisa-se neste texto os discursos ${ }^{7}$ que atravessaram diferentes enunciações documentadas em revistas, jornais e demais documentos, compreendendo que o discurso mais do que representar, constitui os objetos de que fala. $\mathrm{O}$ discurso não se refere ou se reduz à forma do texto ou de um ato de fala individual, mas se constitui como uma prática social bem mais ampla, complexa, variada em suas múltiplas proveniências. Trata-se de uma análise histórica que parte de uma série documental para intercruzar enunciações que remetem a enunciados diversos que, por sua vez, estiveram articulados a discursos de longo alcance. $\mathrm{O}$ discurso da filantropia que emergiu nos anos 1930 com pretensões científicas e higienistas procurou diferenciar-se do discurso da caridade religiosa, marcante desde o século XVI.

A filantropia articulou-se no momento em que "o social" passou a ser definido e problematizado como campo de atuação para profissionais e pessoas treinadas para lidar cientificamente com questões como a pobreza, delinquência, maternidade e demais "problemas sociais" ". Em seu estudo genealógico sobre a "ascensão do social”, Jacques Donzelot $^{9}$ pesquisou o contexto francês no século XVIII, descortinando as práticas médicas e judiciárias que criaram variações na concepção de família tomada como objeto de intervenções diversas. ${ }^{10}$

Em um espaço de experiência marcado pela carência como aquele em que emergiu a LBA na Paraíba, a elaboração de um horizonte de expectativa mobilizando esperanças e promessas para um tempo novo foi algo estratégico para elaborar um imaginário um imaginário capaz de legitimar escolhas políticas e projetos de governo da infância. Mas cabe perguntar: Por que governar a infância? A respeito disso, Alfredo Veiga-Neto afirma que "governar a infância significa educar as crianças, moldando-lhes a alma que é, ao mesmo tempo, efeito e instrumento de uma anatamopolítica dos e sobre os corpos

\footnotetext{
${ }^{7}$ Considero o desafio metodológico lançado por Foucault nos seguintes termos: "não mais tratar os discursos como conjunto de signos (elementos significantes que remetem a conteúdos ou a representações), mas como práticas que formam sistematicamente os objetos de que falam. Certamente os discursos são feitos de signos; mas o que fazem é mais que utilizar esses signos para designar coisas. É esse mais que os torna irredutíveis à língua e ao ato de fala. É esse 'mais' que é preciso fazer aparecer e que é preciso descrever”. Cf. FOUCAULT, Michel. A arqueologia do saber. Tradução de Felipe Baeta Neves. $8^{a}$ ed. Rio de Janeiro: Forense Universitária, 2016, p. 55.

${ }^{8}$ Sobre uma análise da formação da "questão social" no Brasil e as políticas sociais a partir da década de 1930, cf. BEHRING, Elaine Rossetti. Política social: fundamentos e métodos. $9^{a}$ ed. São Paulo: Cortez, 2011.

${ }^{9}$ DONZELOT, Jacques. A polícia das famílias. Tradução de Maria Thereza da Costa Albuquerque. Revisão técnica de J. A. Guilhon de Albuquerque. $2^{\mathrm{a}}$ ed. Rio de Janeiro: Edições Graal, 1986.

${ }^{10}$ Para uma análise da interferência da medicina na organização familiar brasileira na virada do século XVIII para o XIX, cf. COSTA, Jurandir Freire. Ordem Médica e Norma Familiar. $2^{\mathrm{a}}$ ed. Rio de Janeiro: Edições Graal, 1983.
} 
infantis". ${ }^{11}$ Assim, "se governa a infância a fim de que aqueles que não estavam aí passem a estar aí, de modo que aqueles que não faziam parte da nossa cultura passem a fazer parte dela, a fim de que os não integrados integrem-se a nós". ${ }^{12}$

Ora, isso parece estar relacionado - não direta nem necessariamente, mas estrategicamente - com uma certa concepção progressiva e linear do tempo histórico. Falar em tempo histórico significa pensar sobre como as experiências individuais e coletivas são articuladas narrativamente para atribuir sentidos e perspectivas sobre o que se faz, pensa, cria, projeta, intui e mobiliza. Significa a articulação de estratos temporais diversos como presente, passado e futuro, na ótica de abordagem daquilo que se transforma. Contudo, como afirma Marlon Sarlomon, "a multiplicidade dos tempos históricos é algo que incomoda e desconcerta o espírito historiográfico"13, pois

habituado ao tempo unívoco, liso, coeso, incolor, orientado, sucessivo, encadeado, axial, progressivo, cumulativo, o espírito historiográfico parece hesitar diante da própria ideia de um tempo histórico formado por uma série de tempos, constituído por inúmeras linhas e camadas do tempo, composto por diversas dimensões e por um emaranhado de temporalidades. ${ }^{14}$

No caso em análise, o tempo histórico foi atribuído com significados específicos para que a criança fosse lida como um lugar de sujeito a ser ocupado por indivíduos treinados para determinadas funções e experiências no mundo do trabalho e da cidadania. Entretanto, insiro aqui o que nos diz o pensador indiano Ashis Nandy sobre a relação entre tempo e infância, por ser uma provocação relevante:

Na medida em que o próprio estado adulto é valorizado como um símbolo de completude e como um produto final de crescimento ou desenvolvimento, a infância é vista como um estágio imperfeito e transitório a caminho da condição adulta, normalidade, socialização completa e condição humana. Isso é a teoria do progresso aplicada ao ciclo de vida do indivíduo ${ }^{15}$.

O tempo histórico que soa aparentemente muito abstrato e generalizado se constitui efetivamente na materialidade do corpo, dos espaços geográficos e das

\footnotetext{
11 VEIGA-NETO, Alfredo. Por que governar a infância? In. RESENDE, Haroldo de. (Org.). Michel Foucault - o governo da infância. Belo Horizonte: Autêntica, 2015, p. 49-56.

12 VEIGA-NETO, p. 55.

${ }^{13}$ SARLOMON, Marlon. Heterocronias: estudos sobre a multiplicidade dos tempos históricos. Edições Ricochete: Goiânia, 2018, p. 9.

${ }^{14}$ SARLOMON, p. 9.

15 NANDY, Ashis. Reconstruindo a infância: uma crítica à ideologia da idade adulta. A imaginação emancipatória: desafios para o século XXI. Organização e revisão técnica de Lucia Rabello de Castro. Tradução de Joannes de Knegt. Belo Horizonte: Editora UFMG, 2015, p. 228.
} 
instituições sociais. Todos estes elementos relacionam-se com heranças que garantirão permanências em relação ao passado, mas também com as descontinuidades e rupturas. Nesse contexto vale lembrar que a infância é uma invenção moderna, como nos informou Philippe Ariès, ${ }^{16}$ e um dos efeitos centrais disso foi a construção de faixas etárias ou divisões em idades da vida, estabelecendo diferenças entre criança, adolescente, jovem, adulto e velho. Entretanto, como nos alertou o sociólogo Pierre Bourdieu, "as divisões entre as idades são arbitrárias" ${ }^{17}$, uma vez que os sentidos de infância, juventude e velhice são agenciados socialmente a partir de critérios e relações variadas e conflitivas, mas jamais podendo ser tomadas como algo natural.

\section{Direitos da criança, horizonte para a infância}

Figura 1 - Os meninos e o fotógrafo

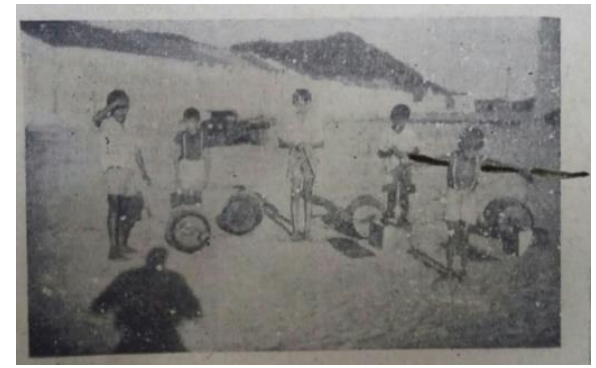

Fonte: jornal A União, 1 de janeiro de 1942. Acervo: Fundação Casa de José Américo de Almeida, PB

Ainda não era meio-dia, mas o sol em Brejo do Cruz - cidade do interior paraibano a 420 km da capital João Pessoa - já estava a pino. Forte, intenso e pouco motivador para quem precisava caminhar carregando galões de água como as crianças fotografadas pelo jornal A União no primeiro dia de 1942, a estiagem e o sol castigavam. Narrava-se ainda a viagem de Gaspar de Paiva, diretor da Repartição de Saneamento do governo de Ruy Carneiro às cidades a fim de realizar uma cartografia da seca; informava o percurso desse engenheiro e o abastecimento de cidades como Brejo do Cruz, Antenor Navarro, Cajazeiras, São João do Cariri e Cabaceiras.

O início das décadas de 1940 e 1950 foi marcado por duas intensas estiagens e naquela época a produção de uma série de notícias sobre o problema da seca apareceu

\footnotetext{
${ }^{16}$ ARIÈS, Philippe. História social da criança e da família. Tradução de Dora Flaksman. Rio de Janeiro: LTC, 2006.

${ }^{17}$ BOURDIEU, Pierre. A juventude é só uma palavra. In. Questões de Sociologia. Tradução de Miguel Serras Pereira. Lisboa: Fim de Século, Edições Sociedade Unipessoal, LDA, 2003, p. 151-152.
} 
nos jornais. O tema da seca no Nordeste ${ }^{18}$ se tornou uma questão central para destinação de investimentos financeiros do governo central por meio da Inspetoria de Obras Contra as Secas criada em 1909. Em 1919 foi acrescentado o termo "federal", tornando-se a Inspetoria Federal de Obras Contra as Secas (IFOCS). Em 1945, por fim, tornou-se o Departamento Nacional de Obras Contra as Secas (DNOCS). ${ }^{19}$

Da imagem pode-se ver que entre as cinco crianças uma outra presença se fez de forma sorrateira. Tratava-se do fotógrafo. Ele apareceu por meio de sua sombra que, intrusa, expôs uma presença que deveria ser apagada em benefício do registro fotográfico oficial e imparcial. Tal detalhe permite entender os porquês dessa inquietante presença em cena. Ele segura o equipamento que capturava a imagem e a permitiria chegar noutros tempos, habitar outros espaços. As imagens fabricadas pela comissão estadual da LBA e outros órgãos do governo narravam os investimentos em prol da infância, lendo a criança como "sementeira do futuro".

Estas imagens permitem pensar, como nos sugere Reinhart Koselleck, que "a experiência é o passado atual, aquele no qual acontecimentos foram incorporados e podem ser lembrados". ${ }^{20}$ Mas tal relação se dá por meio de tensões que configuram a experiência do tempo, algo contido no conceito de horizonte de expectativas. A expectativa "é ao mesmo tempo ligada à pessoa e ao interpessoal" e "também a expectativa se realiza no hoje, é futuro presente, voltado para o ainda não, para o não experimentado, para o que apenas pode ser previsto". Portanto, "esperança e medo, desejo e vontade, a inquietude, mas também a análise racional, a visão receptiva ou a curiosidade fazem parte da expectativa e a constituem". 21

Os conceitos de espaço de experiência e horizonte de expectativa na leitura de Koselleck não constituem um par de opostos, uma dicotomia, mas implicam-se mutuamente. Permitem entender o tempo histórico e a relação entre o passado e o futuro,

\footnotetext{
${ }^{18}$ O Nordeste foi inventado como recorte espacial a partir de 1910 em um campo de forças em que se fez das estiagens uma forma de barganha política e produção de clivagens regionais. Sobre isto, ver: ALBUQUERQUE JÚNIOR, Durval Muniz de. A invenção do Nordeste e outras artes. $5^{\text {a }}$ ed. São Paulo: Cortez, 2011.

${ }^{19}$ Para maiores detalhes sobre este órgão federal, cf. Centro de Pesquisa e Documentação de História Contemporânea do Brasil (CPDOC) da Fundação Getúlio Vargas (FGV). Disponível em: http://cpdoc.fgv.br/sites/default/files/verbetes/primeirarepublica/INSPETORIA\%20FEDERAL\%20DE\%20OBRAS\%20CONTRA\%20AS\%20SECAS.pdf. Acesso em 18 de mar. 2021.

${ }^{20}$ KOSELLECK, Reinhart. Futuro Passado: contribuição à semântica dos tempos históricos. Tradução do original alemão Wilma Patrícia Maas, Carlos Almeida Pereira. Revisão da tradução de César Benjamin. Rio de Janeiro: Contraponto; Ed. PUC-Rio, 2006, p. 309.

${ }^{21}$ KOSELLECK, p. 310.
} 
pois ambos são articulados no/pelo presente. Em Koselleck fica clara a sua percepção sobre a modernidade e como ela foi fundamental para uma nova concepção de tempo histórico, pois a ideia de profecia - muito cara ao discurso religioso cristão do medievo foi transformada ou superada por uma ideia de expectativa como projeção/produção de futuro.

Entretanto, se o Boletim a todo o tempo fazia referência a um "tempo novo", cabe pensar um pouco sobre o que significaria, pois “só se pode conceber a modernidade como um tempo novo a partir do momento em que as expectativas passam a distanciar-se cada vez mais das experiências feitas até então". ${ }^{22}$ Assim, para lidar com a infância, uma das linhas de argumentação pode ser percebida na seção Direitos da Criança Brasileira, que apareceu no Boletim em uma edição de 1947, sendo descontínua. Assim como no plano internacional a ONU coordenava um processo que culminaria no mês de dezembro na DUDH, também localmente a Paraíba produziu narrativas sobre esse tema a partir das orientações da comissão central da LBA e do Departamento Nacional da Criança (DNCr). O Boletim conferia visibilidade para as definições jurídicas e técnicas dos órgãos ligados às políticas para a infância. No mês de agosto de 1948 tal seção trazia aqueles direitos definidos pelo DNCr, órgão que fazia parte da estrutura do Ministério da Saúde, criado em 1953.

A toda a criança nascida ou residente no Brasil reconhecemos os seguintes direitos, empenhando-nos, cada um na medida de suas fôrças (sic), por proporciona-los, sobretudo àquelas a quem a má sorte feriu ou deixou ao desamparo:

1) Ser atendida desde o seio materno, e nascer bem, evitados o quanto possível os riscos de morte, doença ou deformação;

2) Ser criada sob o carinho maternal e no ambiente da família, ou, na falta dêste (sic), num que se lhe aproxime o mais possível;

3) Nunca sofrer fome ou penar por insuficiencia (sic) de elementos nutritivos indispensáveis;

4) Ser tratada como criança, e como tal respeitada e atendida nos seus justos interesses e aspirações;

5) Receber os princípios de educação que a preparem para a vida, e lhe permitam tomar consciência do seu próprio destino;

6) Receber assistência médica e higiênica que lhe evite riscos de doença e de morte;

7) Jamais ficar abandonada à sua sorte, sem amparo material, social e moral eficiente e carinhoso;

8) Não ser menosprezada por motivos de família, iligitimidade (sic), nobreza, raça, religião, deformidade física ou mental;

${ }^{22}$ KOSELLECK, p. 314. 
9) Nunca ser vítima de crueldade ou exploração, nunca ser submetida a trabalhos que lhe possam prejudicar o desenvolvimento normal e a saúde, o caráter, a educação, a liberdade, a alegria de viver;

10) Nunca permanecer segregada de convivência social, proporcionada às suas condições pessoais;

11) Não ser considerada criminosa e responsável quando em falta social, devendo em caso receber assistência judiciária especializada e os corretivos adequados;

12) Ser com sua mãe a primeira a receber socorros em caso de calamidade pública ${ }^{23}$.

Ao DNCr "competia estudar e divulgar o 'problema social da maternidade, da infância, e da adolescência'[...] e conceder auxílio federal aos Estados e subvenção às instituições de caráter privado" 24 e fiscalizar as ações. A infância aparece no Boletim na articulação com a família, com o Estado e com a ideia de saúde. A seção dedicada para aos direitos da criança demonstrava a tecnologia biopolítica ${ }^{25}$ que dava conteúdo à atuação do Estado no controle sobre a vida das crianças. Um dos dispositivos de maior eficiência foi a biorregulamentação que na Paraíba caracterizou-se no Serviço de Bioestatística do Departamento de Saúde. Como a citação acima sugere, o Boletim articulou uma definição dos direitos da criança.

Mas, o que significa definir direitos?

Considerando-se que a definição dos direitos civis, políticos, sociais, culturais e econômicos ocorre em espaços tensionados pela sociedade civil, mas formulados por meio de legislação específica que definirá as ações dos Estados e seus governos, pode-se pensar que a tarefa de definir direitos seja, em primeiro lugar, aquela que se caracteriza pela mediação entre um passado histórico que incide sobre o presente, na conformação de demandas e problemas que devem ser coletivamente encarados como objeto de definição e intervenção. Em segundo lugar, a atividade de definir um rol de direitos

\footnotetext{
${ }^{23}$ Boletim da LBA, Ano II, Agosto de 1948, Número 12, p. 05.

${ }^{24}$ RIZZINI, Irma. Meninos desvalidos e menores transviados: a trajetória da assistência pública à infância até a Era Vargas. In. RIZZINI, Irene \& PILOTTI, Francisco (orgs.). A arte de governar crianças: a história das políticas sociais, da legislação e da assistência à infância no Brasil. $3^{\text {a }}$ ed. São Paulo: Cortez, 2011, p. 270.

${ }^{25}$ Compreendo com Foucault que a biopolítica "lida com a população, e a população como problema político, como problema a um só tempo científico e político, como problema biológico e como problema de poder". Tal problematização surgiu no século XVIII, produzindo uma série de efeitos no modo como os Estados Nacionais iriam lidar com a questão da população. Construiu-se historicamente a biopolítica como forma de "levar em conta a vida, os processos biológicos do homem-espécie e de assegurar sobre eles não uma disciplina, mas uma regulamentação", tratando-se, portanto, de uma tecnologia que articula saber e poder para o governo da população, ou seja, “um poder contínuo, científico, o poder de 'fazer viver'. A soberania fazia morrer e deixava viver. E eis que agora aparece um poder que eu chamaria de regulamentação e que consiste, ao contrário, em fazer viver e deixar morrer". Cf. FOUCAULT, Michel. Aula de 17 de março de 1976. In. Em defesa da sociedade. Tradução de Maria Ermantina Galvão. $2^{a}$ ed. São Paulo: Editora WMF Martins Fontes, 2010, p. 201-222.
} 
ancora-se em um "diagnóstico" social e demográfico que articula práticas de definição, prescrição e normalização em espaços institucionalmente delimitados. Diante disso, torna-se relevante situar a formulação jurídica em uma rede social mais ampla e complexa, pois como sugere Bourdieu, deve-se evitar na análise do discurso jurídico tanto as óticas do "formalismo, que afirma a autonomia absoluta da forma jurídica em relação ao mundo social, e do instrumentalismo, que concebe o direito como um reflexo ou um utensílio ao serviço dos dominantes". ${ }^{26}$

Historicamente a afirmação de direitos tem como premissa básica o fato de eles não serem mera delegação do Estado. A conquista dos direitos se deu em lutas e resistências que somente a análise de um campo social eivado de tensões permite entender. ${ }^{27}$ Exemplo disso se lê na obra de Lynn Hunt que, ao contar a história cultural dos direitos humanos, mostra como desde o século XVIII a linguagem dos direitos humanos passou por transformações. Tais direitos não foram afirmados em processos pacíficos, mas em conflitos entre colonos e colonizados, entre grupos econômica e politicamente influentes sobre grupos alijados da possibilidade de participação. Fazendo a história das narrativas em torno dos "direitos do homem", posteriormente expressos como "direitos humanos" - embora esse termo tenha sido usado pela primeira vez por Voltaire no Tratado sobre a Intolerância (1763) -, Hunt afirma que "os direitos humanos não são apenas uma doutrina formulada em documentos: baseiam-se numa disposição em relação às outras pessoas, um conjunto de convicções sobre como são as pessoas e como elas distinguem o certo e o errado no mundo secular". ${ }^{28}$

A história dos direitos humanos como conceito ético, filosófico e político tem longa data e foi marcado por conquistas travadas diante de conflitos com dimensões de classe e dominações pautadas nas relações entre o masculino e o feminino, o secular e o religioso. No Brasil, os direitos da criança passaram a ser nomeados a partir de 1927 com o Código de Menores. Mas é sabido que ali o conceito de "menor" como sujeito de desvio foi o que preponderou. ${ }^{29}$ A noção e a imagem da criança foram articuladas em outros

\footnotetext{
${ }^{26}$ BOURDIEU, Pierre. A força do direito: elementos para uma sociologia do campo jurídico. In. O poder simbólico. Tradução de Fernando Tomaz. Lisboa: DIFEL, 1989, pp. 210-254.

${ }^{27}$ Para um exercício de sociologia histórica que analisa processos de luta e resistência que, no contexto brasileiro, fez nascer conquistas jurídico-políticas, ver: GOHN, Maria da Glória. História dos Movimentos e Lutas Sociais: a construção da cidadania dos brasileiros. 7ª ed. São Paulo: Edições Loyola, 2012.

${ }^{28}$ HUNT, A invenção dos direitos humanos, p. 25.

${ }^{29}$ Cf. LONDOÑO, Fernando Torres. A origem do conceito Menor. In. DEL PRIORE, Mary (Org.). História da criança no Brasil. São Paulo: Contexto, 1996, pp. 129-145.
} 
agenciamentos. Na Constituição de 1934 fez-se a menção direta ao povo, à população, e como analisa a historiadora Céli Regina Jardim Pinto,

pela primeira vez o país é nomeado como composto de um conjunto de pessoas organizadas em famílias, por sexos diferentes, em estágios geracionais diversos, com diferentes graus de riqueza, com direitos específicos e particulares e, mais importante do que tudo isto, uma população de trabalhadores, com direitos assegurados. [...] São o trabalhador e a mulher os grandes incluídos na Constituição de $1934 .{ }^{30}$

Tal carta pretendeu assegurar um leque de direitos, reconhecendo a variedade dessa população. No que diz respeito às crianças brasileiras, desde o período colonial havia ficado sob a responsabilidade da Igreja católica o trabalho de assistência. Maria Luiza Marcílio $^{31}$ analisou a trajetória do abandono da criança, partindo de elementos da história do Ocidente e particularizando a sociedade brasileira. Por meio da etnodemografia e da demografia histórica, articulou informações quantitativas e qualitativas para fazer história social. A legislação sobre a infância no período de 1920 a 1950 foi gestada na interação de médicos, pedagogos, juristas, assistentes sociais, puericultores e outros autorizados a normatizar a infância e a criança. Se tratava de criar uma maquinaria política capaz de gerenciar os problemas da sociedade, como se lê nesse trecho:

\section{COMO A CRIANÇA DEVE VIVER}

A criança deve viver alegre como um passarinho... Mas o melhor meio de conseguir isso é o exemplo dos adultos. É preciso constituir em torno da criança um ambiente de tranquilidade e de otimismo. Mesmo diante de uma ocorrência de certa gravidade não devemos mostrar na presença das crianças o nosso estado de apreensão, angústia ou desespero.

A preocupação excessiva com a saúde da criança é outro erro a evitar [...]. Mania não menos perniciosa é a de remédios desnecessários, tomando muitas vezes o lugar de um regimen (sic) de vida apropriado, com uma dose maior de ar e de sol [...]..

A criança sadia deve considerar a consulta ao médico ou ao dentista como um ato da vida, destinado a melhorar nossas condições de saúde. ${ }^{32}$

Articulando a citação acima com a imagem que dá início a esta seção, se vê que na imagem há crianças carentes, necessitando de água, enquanto o texto propõe uma concepção idílica de criança. Na história da Paraíba duas grandes estiagens marcaram as décadas de 1940 e 1950, caracterizando um fenômeno curioso, pois "desde 1922 que as

\footnotetext{
${ }^{30}$ PINTO, Céli Regina Jardim. Foucault e as Constituições Brasileiras: quando a lepra e a peste encontram os nossos excluídos. Educação \& Realidade, Porto Alegre, v. 24, n. 2, jul-dez. 1999, p. 44.

${ }^{31}$ MARCÍLIO, Maria Luíza. História social da criança abandonada. São Paulo: Editora Hucitec, 1998, p. 21.

${ }^{32}$ Boletim da LBA, Ano I, Agosto de 1947, n. 4, p. 8.
} 
secas no nordeste brasileiro assumiram um caráter cíclico", sendo "verificadas a cada dez anos"33. Mudanças estavam em curso, pois com o fim do Estado Novo (1937-1945) os líderes do governo estadual não seriam mais definidos pelo presidente da República, mas por voto direto. Ao usar o conceito de "redemocratização" para se referir ao processo pós1945, José Murilo de Carvalho analisa que o período foi marcado por um sopro de democratização dos processos decisórios. Mas é preciso relativizar isto, uma vez que o presidente foi deposto por meio de um golpe. Para Carvalho o critério de análise vinculase ao voto direto e a extensão dos direitos civis e políticos, esculpidos nas três constituições do período, ao passo em que "os movimentos sociais independentes avançaram lentamente". ${ }^{34}$ O autor considera o período de 1930-1945 como a "era dos direitos sociais", tendo sido ali que se construiu as bases da legislação trabalhista e previdenciária. Todavia, os trabalhadores do campo continuaram fora da política social, o que mudou somente a partir de 1963 com o Estatuto do Trabalhador Rural.

Na Paraíba o período foi marcado pela gestão de dois governadores, Oswaldo Trigueiro (UDN - 6 de março de 1947 a 30 de junho de 1950) e José Américo de Almeida (PL - 31 de janeiro de 1951 a 31 de janeiro de 1956). Sobre a gestão de José Américo, especificamente, a pesquisa de Jivago Barbosa $^{35}$ estudou a política assistencialista. $\mathrm{O}$ estado se encontrava em difíceis condições financeiras. Barbosa discutiu o papel da mídia, pois se o jornal A Imprensa havia sido fechado durante o governo de Ruy Carneiro, por outro lado no momento em que José Américo esteve no governo estadual este órgão desempenhou uma importante função de crítica. O periódico pertencia à Arquidiocese, sendo dirigido pelo cônego Odilon Pedrosa e se tornou importante meio de comunicação ao questionar a imagem do governador como "benfeitor" e "salvador dos sertões". A Imprensa fazia frente à imagem propagada pelo jornal $A$ União. Pois "ainda que muitas vezes marcasse uma oposição um tanto dúbia - ora a favor das propostas sobre a seca, ora atacando o governo em setores vitais" $" 36$ - este jornal desempenhou papel crucial "no sentido de divulgar algumas ações estatais que não lograram êxito durante os anos de 1951-1952”. Tratava-se do jornal com a segunda maior tiragem e circulação na cidade de João Pessoa e em parte da Paraíba. ${ }^{37}$

\footnotetext{
${ }^{33}$ A União, terça-feira, 13 de março de 1951, p. 4.

${ }^{34}$ CARVALHO, José Murilo de. Marcha acelerada (1930-1945). In. Cidadania no Brasil: o longo caminho. $10^{a}$ ed. Rio de Janeiro: Civilização Brasileira, 2008, p. 87-88.

${ }^{35}$ BARBOSA, Jivago Correia. Política e assistencialismo na Paraíba: o Governo de José Américo de Almeida (1951-1956). Dissertação (Mestrado em História). Universidade Federal da Paraíba, 2012.

${ }^{36}$ BARBOSA, p. 241.

${ }^{37}$ BARBOSA, p. 241.
} 
Durante o governo de José Américo de Almeida o investimento na causa da infância foi articulado aos problemas da seca e da mortalidade infantil. Ainda no início do governo, A Imprensa divulgou matéria sobre isso, posicionando-se em relação ao documento "Exposição de motivos", escrito por Osias Nacre, secretário do Interior e Segurança Pública, sobre os problemas de assistência social. O autor se referia aos serviços assistenciais conduzidos pelo cônego José Coutinho nos seguintes termos:

a distribuição de auxílio em dinheiro a mais de quinhentos necessitados, ambulatório de clínica geral, limitado a trinta consultas diárias e visitação médica a domicílios, duas vezes por semana; ensino rudimentar a crianças filhas de mendigos, com uma 'tentativa de iniciação profissional' e o fornecimento de refeições à infância desajustada; e um serviço de recolhimento, para atender a indigentes em parte chegados do interior em busca de socorro médico. ${ }^{38}$

Apesar de que se trata de duas conjunturas bastante semelhantes sob alguns aspectos, pode-se ver transformações em relação aos governos de José Américo de Almeida e o de Ruy Carneiro no tocante à infância. Ainda no governo de Oswaldo Trigueiro, quando a Paraíba contava com uma população de 1.685 .400 habitantes, com apenas 169 médicos e 03 enfermeiras, tentou-se a criação de uma Escola de Enfermagem de alto padrão. ${ }^{39}$ Isso ocorreu no momento em que a ONU havia aprovado a criação do Fundo Internacional de Socorro à Infância (FISI) para prestar cooperação aos países mais pobres com acesso à alimentação e demais suportes aos governos por meio de acordos de cooperação.

O plano de Oswaldo Trigueiro, porém, esbarra em dificuldades de repasse de verbas e se amortece diante das exigências de outros Estados nordestinos de serem incluídos na distribuição dessas verbas, redundando numa 'iniciativa fracassada"" devido à "inviabilidade e a insignificância do montante que caberia a cada Estado, caso a verba fosse assim repartida. ${ }^{40}$

No fim do primeiro trimestre de sua administração, José Américo informou o poder legislativo sobre suas ações. Em sua gestão o contato com o FISI, almejado por Oswaldo Trigueiro, se efetivou. Por meio da representação do embaixador João Carlos Muniz, o Brasil assinou o pacto de cooperação com o comitê executivo do FISI,

\footnotetext{
${ }^{38}$ A Imprensa, 14 de fevereiro de 1951. In. Barbosa, 2012, p. 241.

${ }^{39}$ LIMEIRA, Maria das Dores \& FORMIGA, Zeluiza da Silva. UFPB: Implicações Políticas e Sociais de sua História. Núcleo de Documentação e Informação Histórica Regional da Universidade Federal da Paraíba, 1986. Disponível em: http://www.ndihr.ufpb.br/programa/ufpb_implicacoes.html. Acesso em 25 de dez. 2016.

${ }^{40}$ LIMEIRA, 1986, s/p.
} 
representado por Maurice Pate. A mensagem do governador, enviada para a Assembleia Legislativa em $1^{\circ}$ de junho de 1951, dizia o seguinte:

O que mais interessa é transportar estoques para todo o nordeste, destinados à revenda com margem limitada de lucro, resolvendo-se, desde logo, o mais angustioso problema nacional que é o do custo da vida, sempre agravado no nordeste nas irrupções de seca. Mormente nesta hora de exaustão. Seriam então organizados os serviços públicos de preferência os de evidente utilidade, abrangendo o maior número de municípios, para evitar a mobilidade interna e as emigrações entre os Estados, fatores de agravação do problema. O ministério da Educação mandaria missões médicas e enfermeiras, como em 1932, para a vacinação sistemática e completa assistência médico-sanitária, conjurando-se os surtos epidêmicos, como já se vem manifestando no açude "Condado". Nessa emergência, a população desamparada, como os inválidos e famílias sem arrimo, exige uma assistência racional de grandes proporções, por se achar esgotada a própria capacidade de dar esmolas ${ }^{41}$.

Presta-se contas ao legislativo sobre suas ações, mas reforça-se as imagens de sofrimento, seca, pobreza e carência do povo. O governador fala da aproximação com o FISI, criado em 1946 (mesmo ano de criação da Organização Mundial de Saúde - OMS) com o intuito de prestar cooperação e assistência na área de nutrição e alimentação para crianças, adolescentes, gestantes e mães lactantes. O trecho, apesar de longo, permite detalhar isto.

\begin{abstract}
Além das instituições beneficentes e das corporações militares, os Institutos poderiam ser mobilizados para uma tarefa de tamanha envergadura, cuja solução será de empenhar tôdas as forças da solidariedade nacional. Tudo, porém, deverá ser feito em caráter de campanha. Acabo de apelar para o representante do Fundo Internacional de Socorro à Infância, dr. Ismael Martinez Sottomayor, para dar aos seus serviços de fornecimento de leite um critério de emergência. Já em Patos estão morrendo vinte crianças por dia. Creio que contando com ampla cooperação dos órgãos mais adequados, será suficiente a cota constitucional para manter essa organização geral. Os Estados, por sua vez, como estou fazendo com o maior sacrifício, terão de colaborar para sua própria salvação. Nem tudo, porém, já está perdido. Previ esta estruturação para o auge da crise, na hipótese de se acentuar a calamidade por falta de chuvas que ainda poderão sobrevir. Atenciosas saudações. -

JOSE' AMÉRICO."

Daí por diante sabe tôda a Paraíba o que fiz, e o que, não podendo fazer, consegui em incessantes apelos dirigidos ao presidente Getúlio Vargas, já vinculado aos destinos de nossa terra como seu bemfeitor, desde
\end{abstract}

\footnotetext{
${ }^{41}$ Mensagem do Exmo. Governador José Américo de Almeida, no dia $1^{\circ}$ de Junho de 1951 à Assembleia Legislativa da Paraíba.

Disponível: https://archive.org/stream/mensagemparaiba1951esta/mensagemparaiba1951esta_djvu.txt. Acesso em 25 de Dez. 2016.
} 
1932. Antes de qualquer socorro que viesse de fora, abri o crédito extraordinário de $\mathrm{Cr} \$ 6.000 .000,00$ para os seguintes fins:

a) assistência aos inválidos e famílias sem arrimo;

b) abastecimento, mediante revenda ao preço do custo, de géneros de primeira necessidade:

c) admissão aos médicos e auxiliares para assistência médico-sanitária;

d) fornecimento de água às localidades que tiverem seus mananciais exgoiados (sic);

e) localização dos flagelados em fazendas do Estado ou particulares que estiverem em condições de recebê-los;

f) aquisição ou locação de viaturas para transporte de géneros alimentícios e de flagelados;

g) cultura irrigada no leito dos rios mediante a utilização de bombas motores; e

h) admissão de 'engenheiros, agrónomos e técnicos agrícolas e aquisição de instrumentos agrários.

Comissões de Socorro - Servindo-me desses recursos constituí Comissões de Socorro nos Municípios flagelados compostas das pessoas mais representativas, inclusive de elementos oposicionistas, com o fim especialmente de fixar a população, evitando, dessa maneira, as debandadas históricas que, em outros lances, invadiam todos os recantos do Estado, desorganizando seu ritmo de vida $^{42}$.

Diante de um desafio demográfico e institucional dessa natureza, a parceria com o FISI foi importante para atuar em diferentes frentes: a) o controle populacional no território sobre gestão de Almeida; b) o fornecimento de condições básicas para a supressão das necessidades mais imediatas. A parceria com o FISI, firmada em 1950, indica o seguinte:

A. O Fundo, de acôrdo com a sua estimativa das necessidades e dentro dos limites de seus recursos, fornecerá alimentos e outros suprimentos e serviços para a ajuda e assistência às crianças, adolescentes, gestantes e mães Lactantes do Brasil.

B. O Govêrno deverá, de acôrdo com o plano de operações aprovado e sujeito a emendas porventura acordadas mais tarde entre o Fundo e o Govêrno, fornecer alimento (e outros programas especiais) para crianças, adolescentes, gestantes e mães lactantes no Brasil e se compromete a que os alimentos e os suprimentos fornecidos pelo Fundo serão distribuídos para as pessoas indicadas e em benefício das mesmas, de acôrdo com o plano de operações mencionado acima.

C. As quantidades e tipos de alimentos e suprimentos a serem fornecidos pelo Fundo e pelo Govêrno, respectivamente, para o benefício de crianças, adolescentes, gestantes e mães lactantes do Brasil serão determinados periòdicanente de acôrdo com a conveniência das fases sucessivas das operações, por meio de consultas e entendimentos entre o Fundo e o Govêrno.

\footnotetext{
${ }^{42}$ Mensagem do Exmo. Governador José Américo de Almeida, no dia $1^{\circ}$ de Junho de 1951 à Assembleia Legislativa da Paraíba.

Disponível: https://archive.org/stream/mensagemparaiba1951esta/mensagemparaiba1951esta_djvu.txt. Acesso em 25 de Dez. 2016.
} 
D. O Fundo não requererá pagamento em moedas estrangeiras para os suprimentos e serviços fornecidos nos termos dêste Acôrdo e fica entendido que não terá direito ao mesmo. ${ }^{43}$

O surgimento do FISI se deu quando a DUDH estava em elaboração. Esse debate nacional e internacional chegou à Paraíba de diversas maneiras, provocando transformações na relação entre Estado e sociedade. As mudanças inseriam em um conjunto mais ampla de reordenamentos jurídicos e políticos, sendo um exemplo disso o caráter autoritário da Constituição de 1937, como indica Pinto ao mencionar que tal documento "excluía, no sentido mais absoluto da exclusão, ou seja, prendendo, exilando e censurando". Isto foi uma marca do autoritarismo, pois “o estado autoritário é um estado regrado, com a pretensão de que cada cidadão, seja quem for, tenha um lugar definido na sociedade". Ocorre que "para se constituir como pólo de poder, o discurso autoritário necessita ou incluir completamente, ou excluir completamente”. Tal pretensão, embora seja inatingível, faz parte desse modus operandi. Na constituição buscou-se "excluir radicalmente no campo político e incluir, com a mesma radicalidade, no campo social"44, o que sugere complexidades inerentes às formas de governo.

Tais condições de possibilidade para a definiçãa de direitos para as crianças articularam-se ao projeto nacional, algo muito claro no conjunto de direitos divulgado no Boletim da $L B A$, que preconizava: a prioridade em atendimentos médicos; vivência afetiva com os pais e familiares; direito à alimentação básica como recurso vital; reconhecimento da individualidade da "criança" com seus direitos e aspirações singulares; direito à educação como forma de construção da consciência individual sobre o seu "destino"; reconhecimento da importância das condições de salubridade e higiene como de importância fundamental na formação da criança; crítica ao abandono e negligência como geradores de risco à vida; recomendação sobre a não exclusão das crianças por critérios de raça, religião, deformidade física ou mental; combate frontal à crueldade, exploração e exposição da criança por meio de atividade laboral; reconhecimento do direito à convivência social e à inimputabilidade penal diante de "falta" social.

\footnotetext{
${ }^{43}$ Acordo entre o Fundo Internacional de Socorro à Infância e o governo dos Estados Unidos do Brasil. Nova York, 9 de Junho de 1950. Disponível em: http://dai-mre.serpro.gov.br/atosinternacionais/bilaterais/1950/b_10/. Acesso em 26 de Dez. 2016.

${ }^{44}$ PINTO, p. 47.
} 
O reconhecimento da singularidade da criança se deu por meio de saberes como a Psiquiatria, Pedagogia, Psicologia e Serviço Social. ${ }^{45} \mathrm{O}$ trabalho de um autor como Arthur Ramos ${ }^{46}$ nos anos 1930-1950 foi importante para pensar figuras como a criança abandonada e delinquente, a criança com "transtornos" mentais e comportamentais, as relações familiares, e a saúde mental. Foram feitos deslocamentos teóricos da Psicanálise e Psiquiatria para as áreas da Educação e da assistência social pública. A criação da Liga Brasileira de Higiene Mental no Rio de Janeiro em 1923 e do Serviço de Ortofrenia e Higiene Mental (SOHM) em 1933 exemplificam isso. O SOHM foi criado no Instituto de Pesquisas Educacionais durante a reforma do ensino municipal promovida por Anísio Teixeira na gestão de Pedro Ernesto Rego Batista, prefeito por duas gestões (1931-1934 e 1935-1936).

O movimento de interpretação da criança como problema social e político envolveu múltiplos agentes sociais. Este investimento nos saberes sobre a criança ocorreu no contexto latino-americano a partir de várias estratégias e em meio a plataformas políticas. O historiador Eduardo Nunes ${ }^{47}$ estudou os Congressos Pan-Americanos da Criança entre 1916 e 1948, analisando como a definição de políticas públicas de saúde, educação e assistência ocorreu no embate entre governos e outras instituições na América Latina, tendo destacada participação nisso a Organização Pan-Americana de Saúde (OPAS), criada em 1902. Nunes problematiza a imagem da criança como "portadora do futuro" como efeito de uma rede de saberes e projetos políticos que respondiam ao contexto de reorganização econômica e institucional de países latino-americanos a partir da ingerência de instituições europeias e estadunidenses.

A definição dos direitos da criança esteve em meio a alterações na relação públicoprivado. Os cursos de puericultura e as várias atividades relacionadas ao aleitamento materno, cuidados com a higiene corporal da criança e a saúde foram fazendo com que

\footnotetext{
${ }^{45} \mathrm{O}$ pronunciamento do desembargador Vicente Piragibe na aula inaugural do curso de Serviço Social no Laboratório de Biologia Infantil, no Rio de Janeiro em 1937, assim como seu texto publicado no Correio da Manhã em 18 de outubro de 1936, reunidos posteriormente em publicação específica, permite ver como o Serviço Social estava sendo relacionado ao problema da infância em situação de abandono e delinquência. Cf. PIRAGIBE, Vicente. Infância abandonada e delinquente. Rio de Janeiro: Imprensa Nacional, 1937.

${ }^{46}$ Foi um médico brasileiro nascido em Alagoas e que desenvolveu estudos sobre vários temas, sendo um articulador dos debates psicanalíticos na área da educação. Um livro interessante a este respeito é A criança problema. A obra permite pensar temas relacionados com a formação comportamental da criança, as relações familiares e os "vícios" que poderiam contribuir para uma postura delinquencial. Cf. RAMOS, Arthur. A criança problema: a higiene mental na escola primária. $4^{\mathrm{a}}$ ed. São Paulo: Companhia Editora Nacional, 1939, 407p.

${ }^{47}$ NUNES, Eduardo Silveira Netto. A infância como portadora do futuro: América Latina, 1916-1948. Tese (Doutorado em História Social). Universidade de São Paulo, 2011.
} 
médicos, enfermeiras e técnicos da LBA interferissem nas dinâmicas familiares, normalizando práticas. A casa passou a ser vista como um meio de criação dos futuros cidadãos. Daí a proposição de uma arquitetura atenta às influências morais, biológicas e sociais do "meio", como preconizava o Código de Menores de 1927 no Artigo 7º alínea "c": "nenhuma criança pode ser recebida para qualquer dos fins de que se ocupa esta lei: [...] c) em casa de onde tenha sido removida criança, por ser perigosa ou anti-higiênica, ou por qualquer motivo interditada enquanto durar a interdição". ${ }^{48}$ Vê-se ainda como o princípio "fazer viver" foi praticado no oferecimento de bancos de leite e distribuição de leite em pó. Apoiou-se o aleitamento materno "eleito como um problema de governo" 49 e tal estímulo evocava a "arte de ser mãe". 50

A definição dos direitos da criança esteve articulada à condenação à prática do trabalho infantil, uma vez que o Código de 1927 proibia o trabalho de menores de 12 anos. Juridicamente, a relação entre criança e trabalho enfatizou que este não deveria ser um elemento prejudicial à formação da pessoa e ao seu "desenvolvimento normal". Aludia-se ao desenvolvimento físico, biológico, cognitivo e psicomotor, pois os acidentes de trabalho se tornaram frequentes na industrialização brasileira entre fins do século XIX e início do XX, conforme estudo de Esmeralda Moura ${ }^{51}$ sobre mulheres e crianças no trabalho industrial em São Paulo. Entretanto, deve-se reconhecer que o trabalho infantil esteve presente em toda a formação histórica do país, pois crianças indígenas e, posteriormente, crianças negras foram escravizadas em relações laborais de diferentes tipos. ${ }^{52}$ Com isso, não foi a partir do século XIX que o trabalho infantil ganhou visibilidade e foi alvo de crítica. Portanto, pensar dessa forma pode invisibilizar dinâmicas bem mais persistentes nos mundos do trabalho.

No contexto paraibano, o estudo de Suelly Santos ${ }^{53}$ historiciza o trabalho infantil entre 1924 a 1947 por meio do surgimento do Patronato Agrícola Vidal de Negreiros, em

\footnotetext{
${ }^{48}$ REPÚBliCA DOS ESTAdOS UNIDOS DO BRASIL. Código de Menores - consolida as leis de assistência e proteção aos menores. Decreto federal no 17.943-A, de 12 de outubro de 1927.

${ }^{49}$ TEIXEIRA, Kerolyn Daiane. A puericultura nas páginas do jornal em Curitiba, entre a virada do século XX até 1930. Monografia (Graduação em História). Universidade Federal do Paraná, 2010.

${ }^{50}$ Sobre as relações de gênero e a constituição da política social da LBA, cf. COSTA JÚNIOR, José dos Santos. Gênero, infância e política social no Boletim da LBA (Paraíba, 1947-1955). Temporalidades, Belo Horizonte, v. 11, p. 573-588, 2019.

${ }^{51}$ MOURA, Esmeralda Blanco B. de. Mulheres e menores no trabalho industrial: os fatores sexo e idade na dinâmica do capital. Petrópolis: Vozes, 1982.

${ }^{52}$ GÓES, José Roberto de \& FLORENTINO, Manolo. Crianças escravas, crianças dos escravos. In. DEL PRIORE, Mary. História das crianças no Brasil. $7^{a}$ ed. São Paulo: Contexto, 2013, pp. 177-191.

${ }^{53}$ SANTOS, Suelly Cinthya Costa dos. Educação e trabalho para os meninos desvalidos: um estudo sobre o Patronato Agrícola Vidal de Negreiros. Dissertação (Mestrado em História). Universidade Federal da Paraíba, 2015.
} 
Bananeiras. Mobilizando legislação, regulamentos e ofícios, a autora construiu a história da instituição que incorporou o escotismo e a ginástica na educação das crianças. ${ }^{54}$ Criouse uma "pedagogia do trabalho" em que a recuperação da criança desvalida se daria 55 pelo treinamento laboral. ${ }^{56}$

\section{Tempos de espera ou retóricas da esperança?}

As páginas da LBA falavam de um tempo em transformação. Ansiava-se por um bem-estar social. Houve um investimento no sentimento da "esperança" como forma de produzir uma sensibilidade coletiva diante de crises socioeconômicas. Uma determinada percepção do tempo histórico imiscuiu-se na política social voltada para a infância, moldando-a e lhe conferindo conteúdo. Articulando análises do passado histórico e expectativas para o futuro, como temporalidade passível de ser controlada e projetada, toda uma política do tempo foi desenhada nessa rede.

Ao comentar a teorização de Koselleck sobre a temporalidade, José D’Assunção Barros enfatiza que as expectativas "não apenas são constituídas pelas formas de sensibilidade com relação ao futuro que se aproxima, mas também pela curiosidade a seu respeito e pela análise racional que o visa". ${ }^{57}$ Etimologicamente, a palavra "esperança" tem a "raiz indo-européia spe que significa expandir, aumentar, ter êxito, levar qualquer projeto adiante seja ele de ordem física ou psíquica. Spe dará em latim spes e daí a nossa esperança". ${ }^{58}$ A esperança foi usada politicamente para articular projetos, justificar intervenções e legitimar ações.

\footnotetext{
${ }^{54}$ Para uma análise das práticas educativas voltadas para o civismo e a higiene no contexto da Paraíba das décadas de 1930 a 1940, ver: SOARES JÚNIOR, Azemar dos Santos. Sob o signo de higia: os saberes médico-pedagógicos e a construção de um corpo hígido na Paraíba (1930-1940). Revista História da Educação (Online), v. 23, 2019.

${ }^{55}$ Para um estudo sobre esta instituição e seu funcionamento em outro contexto geográfico, cf. BOEIRA, Daniel Alves. Uma "solução" para a menoridade na Primeira República: o caso do Patronato Agrícola de Anitápolis - SC (1918-1930). 138 fls. Dissertação (Mestrado em História). Universidade Estadual de Santa Catarina, 2012.

${ }^{56} \mathrm{O}$ estudo clássico de Edward Palmer Thompson, organizado em três volumes e publicado originalmente em 1963, sobre a Revolução Industrial na Inglaterra do século XVIII, aponta uma série de análises sobre a historicidade do trabalho infantil, as redes sociais em que ele se deu e os conteúdos culturais que o mediou. Cf. THOMPSON, Edward Palmer. A formação da classe operária inglesa: a maldição de Adão, v. 2. $2^{\mathrm{a}}$ ed. Tradução de Renato Busatto Neto e Cláudia Rocha de Almeida. São Paulo: Paz e Terra, 2012.

${ }^{57}$ BARROS, José D'Assunção. Koselleck: o Historicismo e o enigma das temporalidades. In. Teoria da História. $3^{\text {a }}$ ed. Petrópolis, RJ: Vozes, 2014, p. 275.

58 Ver: Sul21. Disponível em: https://www.sul21.com.br/colunas/franklin-cunha/2014/06/a-raiz-daesperanca/\#: : :text=A\%20raiz\%20indo\%2Deurop\%C3\%A9ia\%20da,e\%20da\%C3\%AD\%20a\%20nossa\% 20esperan\%C3\%A7a.. Acesso em 27 de jul. 2020.
} 
Os jornais A União e A imprensa fizeram esse tipo de leitura ao mostrar caminhos alternativos e horizontes possíveis. A esperança como elaboração subjetiva se dava em relação não somente com sonhos e projetos positivos, mas frente a ameaças e incertezas. Em meados de 1952 o Boletim da LBA falava de uma possível "guerra atômica" e os avanços da ciência na arte de matar em massa. Dez anos antes, em 02 de fevereiro de 1942, A União, publicava:

ASSISTÊNCIA À INFÂNCIA

Manuel Florentino

Numa época como a atual em que as nações se arruínam na produção de engenhos de destruição é extranhável talvez que alguém pense em meios para preservar a vida de crianças que, forçosamente, se transformarão depois de mil sacrifícios dos pais e de mil sofrimentos próprios, em simples carne para canhão.

[...] para quem acredita na evolução das cousas, para os que crêem que é justamente nestas épocas de incertezas para a Humanidade que fermentam os grandes acontecimentos que nos demonstram não ser o homem só e besta insaciável de morticínios, este é o momento de pensar no dia de amanhã, na formação de uma juventude otimista, numa mocidade que acredite em alguma cousa de mais valor do que o dinheiro, que tenha como paradigmas não a Napoleão ou a Hitler, mas aos Pasteur e Curies e tantos outros que dignificam a espécie humana e que, no entanto, são olhados na atualidade apenas como sujeitos curiosos, ou tolos que não souberam transformar em moedas (e que belas pilhas de dólares) os frutos de sua inteligência.

É esse otimismo, leitor amigo, que me faz escrever estas linhas, que me faz acreditar em que, após toda esta confusão da época presente, uma sociedade melhor, mais esclarecida, virá substituir a atual, suprimir os preconceitos que hoje entravam o progresso que poderia ser feito pacificamente, se não fosse a falta de lógica e bom senso de gerações que não querem acreditar na perene evolução, na sempre viva mudança das cousas.

Para cuidarmos da criança devidamente, precisamos de começar pelo seu período de formação, pelos meios de que dispomos para fazê-la crescer robusta.

O otimismo expresso nesse texto, todavia, defrontava-se com situações urgentes, conforme o articulista dizia:

[...] Dizia eu que, entre os vários problemas da alimentação racional do nosso povo, o do abastecimento de leite à população do Nordeste está em primeira linha, a merecer cuidados sérios.

Em nossa Capital, com 75.000 habitantes e cerca de 17.000 crianças em idade escolar, isto é, de 7 a 14 anos, não se consomem mais do que uns 4.000 litros de leite diariamente, ou seja, cerca de 50 grs per capita.

Em 1941, para um obituário de 2.604 mortes, 1.310 foram de crianças até 9 anos, assim distribuídas 


\begin{tabular}{|c|c|c|c|c|}
\hline De & 0 & $\mathrm{a}$ & 1 & ano \\
\hline 766 & & & & \\
\hline$"$ & 1 & $\mathrm{a}$ & 2 & , \\
\hline 356 & & & & \\
\hline " & 2 & $\mathrm{a}$ & 4 & , \\
\hline 124 & & & $\ldots$. & \\
\hline , & 5 & $\mathrm{a}$ & 6 & , \\
\hline
\end{tabular}

64

No grupo de 0-1 anos, dos 766 óbitos 536 foram rotulados de - Diarreia e Enterite - o que significa, em sua quase totalidade, doenças gastrointestinais provocadas por desvios da alimentação ou seja - falta de alimentação adequada ou ignorância das mais rudimentares noções de Dietética infantil.

Não é possível que continuemos a trilhar este caminho. Há necessidade imperiosa de estudarmos cuidadosamente a questão em todos os seus pormenores, se queremos de fato fazer Assistência à Infância, povoar o Brasil com brasileiros.

[...] A solução que temos de encontrar pouco difere das que se procurou em outras terras. No entanto, sem que o Governo se ponha a frente desta campanha, nada se conseguirá, porque é ao Estado que compete velar pelo bem coletivo e, em nosso meio, tomar as iniciativas úteis, incompatíveis com o espírito mercantil de nossa sociedade.

Tenho plena esperança em que o atual administrador paraibano, sempre pronto em atender ás necessidades da Paraíba, procurará solucionar esse problema, completando serviços já começados á custa de grandes esforços particulares e criando outros, para serem entregues a paraibanos capazes e amantes de sua terra. Usando a linguagem dos homens de negócio, diríamos - $\mathrm{O}$ dinheiro gasto nesses serviços públicos será recuperado depois com juros compensadores ${ }^{59}$ (grifos meus).

Este texto manifesto aclamava as ações em curso. Em um momento marcado por miséria buscava-se criar referências às quais se direcionar para ancorar projetos e leituras do mundo. Não parece ter sido à toa que intelectuais como Louis Pasteur (1822-1895) e Marie Curie (1867-1934), como se pode depreender do termo "Curies", foram citados para referendar a importância da ciência na organização social.

Assim, vê-se como ações variadas foram compondo um sentimento de esperança, uma aposta no tempo por vir. Peter Burke analisou a esperança na perspectiva de uma história das sensibilidades, caracterizando-a como construção humana que atribui sentido à experiência do tempo. Perguntando-se “a esperança tem história?”, este historiador

\footnotetext{
${ }^{59}$ A União, segunda-feira, 2 de fevereiro de 1942, p. 3.
} 
inglês indica que na perspectiva de uma análise histórica, o primeiro passo seria se desvencilhar dessa ideia de uma Esperança singular, com E maiúsculo, para privilegiar esperanças menores, plurais e variantes.

[...] por "grandes esperanças" quero dizer esperanças de um mundo melhor, esperanças para a raça humana. Por "pequenas esperanças" quero dizer esperanças cotidianas, esperanças de uma vida melhor limitadas a nós e a nossa família, incluindo a esperança de mobilidade social (que aliás, se anularia se todos a realizassem). ${ }^{60}$

Para o autor, "podemos, portanto, falar em horizontes variáveis de esperança", ou "horizonte de expectativas" como assim definem pensadores alemães como Edmund Husserl e Hans-Georg Gadamer que inspiraram Koselleck. Portanto, “a esperança tem uma história, ou mais precisamente, esperanças têm histórias". 61

Diferentes acontecimentos históricos mobilizaram sentimentos coletivos de esperança como em 1776, 1789, 1848, 1910, 1917, 1968 ou 1989, pois "alguns analistas de revoluções acreditam que esses eventos geralmente ocorrem devido a 'expectativas crescentes', isto é, a esperanças que são bloqueadas e, por isso, acabam provocando revoltas". Tais acontecimentos ou "momentos mágicos" afetam o imaginário social, dando "uma renovada sensação de que tudo é possível". ${ }^{2}$ A declaração de 1776 se caracteriza como uma espécie de "carta patente", segundo Burke, para definir o Sonho Americano, assim como a mudança do calendário pela Revolução Francesa de 1789 alimentou a ideia de que "a história humana pudesse começar novamente do zero" e voltar-se para um tempo novo (futuro). Burke afirma que a partir do século XVIII "a esperança foi institucionalizada, ao menos na Europa e nas Américas" ${ }^{63}$. Isso indica como “a esperança tem uma geografia além de uma cronologia”, pois

[...] é esclarecedor comparar e contrastar o sonho francês de liberdade, igualdade e fraternidade para todos, realizado por meio do Estado, com o sonho americano de liberdade e igualdade de oportunidades para indivíduos, e com o sonho brasileiro da fraternidade ou "democracia racial".

Variando sincrônica e diacronicamente, as esperanças respondem a momentos diversos. No caso da LBA e suas políticas para a infância, a esperança foi produzida em

\footnotetext{
${ }^{60}$ BURKE, Peter. A esperança tem história? Estudos Avançados, Universidade de São Paulo, v. 26, n. 75 , 2012, p. 207-217.

${ }^{61}$ BURKE, p. 207.

${ }^{62}$ BURKE, p. 212.

${ }^{63}$ BURKE, p. 213.
} 
uma rede com instituições estatais e da sociedade civil. No texto supracitado do Boletim, se fez um uso crítico e político da noção de esperança em meio a um elogio a Ruy Carneiro. "A solução que temos de encontrar pouco difere das que se procurou em outras terras", dizia o articulista. Defendia-se um Estado forte e interventor que regulava e implementava procedimentos que fizeram da vida um objeto de definição/intervenção. As ações compreendiam o processo de gestação, nascimento, alimentação na primeira infância e desenvolvimento físico e cognitivo por meio de instrução escolar e preparação para o trabalho.

Acreditava-se que era preciso "povoar o Brasil com brasileiros". Contudo, deviase evitar a famigerada "degenerescência da raça", que se referia à leitura brasileira das teorias raciais que chegaram da Europa após $1870 .{ }^{64} \mathrm{O}$ conceito de degenerescência partiu de autores como Benedict August Morel (1809-1873) e foi mobilizado no Brasil por vários intelectuais. Em 1910 o livro Criminalidade da infância e da adolescência, do advogado Evaristo de Moraes, se apropriou da teoria da degenerescência de Morel nos seguintes termos:

A criança nascida de raças de paes debilitados por excesso de trabalho e por falta de alimentação sufficiente - quaes são os operarios, explorados pelo ganancioso industrialismo do nosso tempo - póde ter o aspecto commum de todas as crianças, parecendo, aos olhos dos inexpertos, sadia e capaz de affrontar as agruras da existencia; mas, provavelmente, desde os primeiros tempos do seu contacto com o torvelinho social, se mostrará pouco apta, inferior aos da sua idade, difícil de educar, propensa á ociosidade e ás sugestões dos criminosos. ${ }^{65}$

Passou-se a ler as vidas das crianças em uma chave econômica, imiscuindo-se a economia em dimensões e aspectos não necessariamente de natureza econômica, a priori. Outro trecho da mesma obra de Moraes, em que ele cita o criminalista italiano Alfredo Niceforo (1876-1960), diz: “a miséria é a grande geradora de criminosos, porque é grande geradora de degenerescência" ${ }^{66} \mathrm{O}$ conceito de degenerescência remetia à existência de uma raça pura contaminada por fatores biológicos de raças inferiores gerando a chave de leitura "pobreza = criminalidade", o que continuaria a dar o tom para leituras preconceituosas sobre setores populares e racialmente marcados no país. Tal prerrogativa

\footnotetext{
${ }^{64}$ SCHWARCZ, Lília Moritz. O espetáculo das raças: cientistas, instituições e questão racial no Brasil (1870-1930). São Paulo: Companhia das Letras, 1993.

${ }^{65}$ MORAES, Evaristo de. Criminalidade da infância e da adolescência. $2^{\mathrm{a}}$ edição. Rio de Janeiro: Livraria Francisco Alves, 1927, p. 14-15.

${ }^{66}$ MORAES, p. 15.
} 
alimentou ao longo de décadas um imaginário social discriminatório sobre a criança pobre e negra, especificamente. Portanto, ao ler a infância na chave econômica ${ }^{67}$ estava em questão pensar a alimentação, as condições sanitárias e higiênicas e a habitação para tornar o corpo infantil "robusto". Na primeira metade do século XX a realização dos concursos de robustez teve grande repercussão, sendo que deles participavam os pais e mães desejosos de exibir os filhos. Havia premiação para o corpo da criança que evidenciasse os cuidados de natureza dietética e higiênica que configuravam um corpo são ${ }^{68}$, conforme o ideário eugênico ${ }^{69}$.

Maurício Parada, ao estudar a relação entre o corpo infantil e o corpo nacional diz que até os anos 1930 "apesar de algumas iniciativas governamentais e parlamentares, o tema estava predominantemente associado a eventos patrocinados e desenvolvidos por clubes e organizações privadas". Houve mudança quando o governo Vargas “consolidou uma prática intervencionista a esse respeito e, nesse processo, duas ideias conduziriam a uma nova relação entre política e corpo: a preocupação com a educação e com o civismo"70. Assim, tanto em uma mirada mais ampla sobre o cenário nacional, como em recortes mais regionalizados e locais pode-se ver os redirecionamentos dessa estratégia que articulou uma anátomo-política do corpo e uma biopolítica da população ${ }^{71}$, nos termos foucaultianos.

Mas a articulação corpo infantil e corpo nacional não se deu apenas em um vínculo econômico, mas eminentemente simbólico, pois mobilizou uma determinada percepção do tempo histórico. Todavia, como pensar corpo/nação/tempo nessa articulação biopolítica? Trata-se de imaginar, primeiramente, como uma sociedade organiza para sim um passado, mas também um projeto de futuro. Este, por sua vez, somente poderá ser

\footnotetext{
${ }^{67}$ Para uma discussão sobre como a partir do início do século XX temas não propriamente econômicos foram lidos nessa chave de interpretação para fins de uma economia liberal, cf. FOUCAULT, Michel. Nascimento da Biopolítica. Tradução de Eduardo Brandão. São Paulo: Martins Fontes, 2008.

${ }^{68}$ Para uma análise deste tema, sugiro: BRITES, Olga. Imagens da infância - São Paulo e Rio de Janeiro, 1930 a 1950. 269 fls. Tese (Doutorado em História). Pontifícia Universidade Católica de São Paulo, 1999. ${ }^{69}$ Jerry Dávila afirma que "a eugenia foi uma tentativa científica de 'aperfeiçoar' a população humana por meio do aprimoramento de traços hereditários", uma noção usada de forma quase corriqueira na Europa e nas Américas durante o período entre guerras. Segundo o autor, a América Latina e a Europa "adotaram uma eugenia 'leve', que sustentava que o cuidado pré e neonatal, a saúde e a higiene públicas, além de uma preocupação com a psicologia, a cultura em geral e a forma física melhorariam gradualmente a adequação eugênica de uma população. Cf. DÁVILA, Jerry. Diploma de brancura: política social e racial no Brasil (1817-1945). Tradução de Cláudia Sant’Anna Martins. São Paulo: Editora UNESP, 2006.

${ }^{70}$ PARADA, Maurício. Corpos infantil e nacional: políticas públicas para a criança durante o Estado Novo. In. DEL PRIORE, Mary \& AMANTINO, Márcia (Orgs.). História do corpo no Brasil. São Paulo: Unesp, 2011, p. 351.

${ }^{71}$ Cf., a respeito disso. FOUCAULT, Michel. História da Sexualidade: a vontade de saber, v. 1. Tradução de Maria Thereza da Costa Albuquerque e J. A. Guilhon Albuquerque. 16 ${ }^{\mathrm{a}}$ ed. Rio de Janeiro: Edições Graal, 1988.
} 
efetuado e praticado na medida em que suas prerrogativas, gozos e riquezas forem subjetivadas na materialidade dos corpos, na espessura dos gestos e crenças que uma coletividade partilha em meio a contradições e ambiguidades que também lhe são constitutivas. Assim, diante dos desafios narrados nas páginas do Boletim da LBA e $A$ União, pode-se ver como este segundo veículo de comunicação insistia na aposta de um tempo novo, dizendo que

para quem acredita na evolução das cousas, para os que crêem que é justamente nestas épocas de incertezas para a Humanidade que fermentam os grandes acontecimentos que nos demonstram não ser o homem só e besta insaciável de morticínios", pois compreendia-se que aquele era "[...] o momento de pensar no dia de amanhã, na formação de uma juventude otimista, numa mocidade que acredite em alguma cousa de mais valor do que o dinheiro $[\ldots]^{72}$.

Apostar em pessoas parecia ter o sentido de torná-las aptas para ocupar um conjunto de tarefas previamente traçadas. Se por um lado tal pronunciamento articulavase ao discurso otimista sobre a juventude brasileira $^{73}$, por outro ele circunscreveu horizontes possíveis, sem atentar para a multiplicidade de infâncias e juventudes que tinha como objeto de intervenção.

\section{Considerações finais}

Inserindo-se no campo de estudos sobre a história da infância e mobilizando as ferramentas da analítica foucaultiana, este texto analisou um conjunto de narrativas que entre os anos 1940 e 1950 articulou concepções de criança, infância, cidadania e tempo histórico no Brasil. Foi um momento de redefinição do passado histórico e dos objetivos que deveriam constituir o projeto nacional, daí a importância de gerar novas e eficazes formas de incidir sobre a população por meio de estratégias que organizaram as políticas

\footnotetext{
${ }^{72}$ A União, segunda-feira, 2 de fevereiro de 1942, p. 3.

${ }^{73}$ De diferentes maneiras a relação entre infância, juventude e futuro tem sido articulada na história do Brasil, a depender do momento e das circunstâncias específicas. Isto apresenta uma agenda de estudos para pensar como as dinâmicas intergeracionais delimitam e mobilizam percepções do tempo histórico em meio a projetos ético-políticos perdidos, propostos, negociados e/ou adiados. Para uma análise sobre a relação entre juventude, tráfico de drogas no Rio de Janeiro e esperança na transformação subjetiva, bem como sobre a diferença entre "justiça criminal" juvenil e "justiçamento" de jovens no tráfico, cf. SOARES, Luiz Eduardo. O futuro como passado e o passado como futuro: armadilhas do pensamento cínico e política da esperança. In. ALMEIDA, Maria Isabel Mendes de \& EUGENIO, Fernanda (orgs.). Culturas jovens: novos mapas do afeto. Rio de Janeiro: Zahar, 2006, pp. 121-138.
} 
educativas na saúde, assistência social e economia. Assim, privilegiando no corpus documental o Boletim da LBA na Paraíba, os jornais A União e A Imprensa, pode-se praticar uma análise enunciativa para problematizar como em que condições de possibilidade as narrativas sobre o corpo infantil estiveram articuladas a uma certa concepção de tempo histórico ancorada no futuro como esperança.

A mediação entre infância, temporalidade e política apareceu de diferentes formas ao longo da história das políticas públicas para a infância, adolescência e juventude. Mas ao usar tais termos tivemos o cuidado de caracterizar e observar o contexto de produção. Nesse sentido, falar em política pública significa entender inicialmente como se desenha um conjunto de ações e intervenções diante de um certo estado de coisas tendo como base um repertório que media informações sobre o passado histórico e as demandas do presente. Ao circunscrever tais demandas em termos socioeconômicos passa-se a elaborar planos e projetos de médio e longo prazo que possam intervir nessa realidade descrita e analisada.

Frente a este diagnóstico que somente pode ser realizado por meio do mapeamento diacrônico de mudanças e/ou permanências, desenha-se um conjunto de estratégias e mobiliza-se aparelhos, técnicas, indivíduos, profissões e instituições para implementar e acompanhar as mudanças em curso. Assim, diagnosticar parece ter o sentido de estabelecer relações entre fatores sociais, biológicos e políticos que tornariam possível a mudança de situações como o índice de mortalidade infantil e as estiagens nas décadas de 1940 e 1950. Foi nesse contexto de elaboração e implementação de projetos variados que cuidaram da educação infantil, alimentação, maternidade, entre outros temas, que se pôde ver como um conjunto de narrativas versou sobre a esperança, sobre este sentimento historicamente fabricado, localizado e partilhado por um determinado grupo ou grupos sociais.

A mobilização da esperança funcionou como projeção afetiva e sentimental, mas também como proposição racional, elaborando caminhos possíveis e operando em meio a um discurso legatário do século XVIII que compreendia o futuro como instância controlável. A fabricação da esperança em ações desenvolvidas localmente, mas orientadas nacional e internacionalmente a partir do $\mathrm{DNCr}$ e do FISI/ONU tornou possível a análise dessas interferências em termos de conteúdo e prática política efetiva propiciada pela articulação de saberes médicos, pedagógicos e científicos.

Essa rede composta por linhas variadas configurou ações para a infância e maternidade, assim como tornou possível adaptações na legislação voltada para os 
direitos da criança e do adolescente nas décadas posteriores. Assim, ao falar em política pública também se está falando sobre as insidiosas e (muitas vezes) perigosas políticas de subjetivação em curso. Individual e coletivamente elas moldam gestos, propõem performances, entendimentos do que é o político e a política, ao mesmo tempo em que operam em um reticente campo de forças no qual resistências singulares não deixam de persistir.

Data de submissão: $21 / 03 / 2021$

Data de aceite: 14/06/2021 